\title{
PENGARUH PENGUNGKAPAN IDENTITAS ETIS ISLAM, AGENCY COST DAN INTELLECTUAL CAPITAL TERHADAP KINERJA KEUANGAN (STUDI PADA BANK UMUM SYARIAH YANG TERDAFTAR DI OTORITAS JASA KEUANGAN PERIODE 2016-2018)
}

\author{
Mursidah $^{1}$, Yunina ${ }^{2}$, Meutia Zahara ${ }^{3}$ \\ ${ }_{1,2,3}$ Prodi Akuntansi Fakultas Ekonomi dan Bisnis Universitas Malikussaleh Lhokseumawe \\ $\underline{\text { mursidah@unimal.ac.id }}^{1}$, yunina@unimal.ac.id ${ }^{2}$, $\underline{\text { mutiaz663@ gmail.com }}^{3}$
}

\begin{abstract}
This study aimed to examine the influence of the Islamic ethical indentity disclosure, agency cost, and intellectual capital to the financial performance proxied by return on asset (ROA) in Islamic commercial bank in 2016-2018. Secondary data were used from annual report were published on the website etch Islamic bank between 2016-2018. The purposive sampling method using in this research, so there are theerten Islamic banks are object of research. The analytical method used is multiple linier regresstion analysis using the SPSS 20 softwer program. The results of this study shows that partial of the Islamic ethical identity disclosure have not effect on the financial performance proxied by return on asset (ROA) in Islamic commercial bank, the agency cost have effect negative on the financial performance proxied by return on asset (ROA) in Islamic commercial bank, and intellectual capital have effect positif on the financial performance proxied by return on asset (ROA) in Islamic commercial bank in 2016-2018.
\end{abstract}

Keywords: Islamic ethical identity disclosure, agency cost intellectual capital, financial performance and ROA.

\section{PENDAHULUAN}

Perbankan syariah adalah perbankan yang sistem operasinya berdasarkan ketentuan-ketentuan hukum Islam. Sistem syariah ini di latar belakangi oleh larangan memungut dan meminjam dengan bunga (riba) serta investasi untuk usaha-usaha yang termasuk ke dalamnya (haram). Larangan riba disebutkan dalam Al Qur'an yang artinya "Hai orangorang yang beriman, janganlah kamu memakan riba dengan berlimpat ganda dan bertakwalah kamu kepada Allah supaya kamu mendapat keberuntungan. Peliharalah dirimu dari api neraka, yang disediakan untuk orang-orang yang kafir.”( QS. Ali-imran:130).

Setelah beberapa dekade terakhir, perkembangan perbankan syariah di Indonesia dapat tumbuh dan berkembang secara cepat. Hal ini dibuktikan dengan meningkatnya jumlah Bank Umum Syariah (BUS) dari 6 BUS pada tahun 2009 menjadi 14 BUS pada tahun 2019. Hingga Agustus 2019, terdapat 20 Unit Usaha Syariah (UUS) dan 165 Bank Pembiayaan Rakyat Syariah (BPRS). Pada periode yang sama, jumlah kantor BUS dan UUS meningkat dari 2.201 kantor menjadi 2.273 kantor. Total aset BUS dan UUS sangat meningkat dari tahun 2016 yang nilai asetnya masih $\mathrm{Rp} 356.504$ menjadi $\mathrm{Rp}$ 483.099 triliun pada Agustus 2019 (OJK, 2019).

Dalam mempertahankan dan meningkatkan kepercayaan masyarakat, perbankan syariah melakukan pengungkapan identitas etis Islam (Fadhillah, 2018). Pengungkapan identitas etis Islam yang dilakukan oleh bank syariah dianggap sebagai sebuah informasi bagi investor, karena identitas tersebut memberikan jaminan akan kesesuaian operasi perbankan dengan prinsip-prinsip Islam. Hal tersebut dilakukan karena saat ini mulai muncul dugaan di masyarakat bahwa bank telah melakukan beberapa pelanggaran praktik etika yang bertentangan dengan prinsip syariah (Fadhillah, 2018). Mereka beranggapan bahwa, bank hanya menjadikan nasabah muslim sebagai sasaran objek dalam mencari keuntungan saja dengan dasar lebel syariah yang melekat pada bank tersebut. Sehingga nasabah menjadi yakin dengan prinsip syariah yang dijalakan perbankan sesuai dengan agama yang di anut dan nasabah juga menjadi loyat terhadapnya. Sayangnya, identitas etika bank syariah saat ini dinilai belum diungkapkan secara optimal. (Sukardi \& Wijaya, 2013) menemukan bahwa bank umum syariah nasional belum mengungkapkan identitas etika secara maksimal, khususnya untuk dimensi zakat, pinjaman, dan sedekah.

Faktor lain yang diduga berpengaruh terhadap kinerja keuangan adalah agency cost. Jensen \& Meckling, (1976) dalam Muhibbai \& Basri, (2017) mengatakan bahwa pemisahan fungsi pengelolaan dan fungsi kepemilikan sangat rentan dengan konflik kepentingan (agency conflict). Agency conflict dapat menimbulkan biaya agensi (agency cost), yaitu berupa pemberian insentif yang layak kepada manajer serta biaya pengawasan untuk mencegah terjadinya kecurangan atau penyalahgunaan wewenang. Ketika para principal berupaya untuk mengendalikan sumber daya organisasi, maka orientasinya adalah untuk 
meningkatkan kesejahteraan mereka. Kesejahteraan tersebut diwujudkan dengan semakin tingginya return yang dihasilkan oleh organisasi maka semakin besar biaya yang dikeluarkan oleh principal untuk membayar agen dalam memantau dan memastikan manajer bertindak konsisten dan sesuai dengan persetujuan kontrak antara manajer, principal dan kreditur.

Selain kedua faktor tersebut, intellectual capital juga menjadi salah satu faktor penting untuk diperioritaskan. Hal ini terjadi seiring dengan berkembangnya teknologi informasi, sehingga perusahaan perlu mengubah strategi bisnisnya menjadi knowledge based business agar dapat bertahan dalam persaingan global. Intellectual capital perusahaan merupakan kekayaan tidak berwujud perusahaan yang terdiri dari pengetahuan yang dimiliki karyawan perusahaan beserta pengetahuan yang terbentuk dalam peralatan dan jaringan yang berpartisipasi dalam kegiatan operasi perusahaan (Thomas Stewart, 1998) dalam (Muhibbai \& Basri, 2017).

Saat ini, dunia industri keuangan syariah sedang mengalami keterbatasan SDM unggul. Hal tersebut dibenarkan oleh Wakil Ketua Dewan Komisaris Syariah Nasional Majelis Ulama Indonesia (DSN-MUI) Prof Dr Yunahar Ilyas Lc MA. (Investor, 2019). Sebagaimana dilansir OJK pada statistik perbankan syariah Agustus 2019, terjadinya penurunan jumlah tenaga kerja pada bank umum syariah dari 51.110 pekerja pada tahun 2016 menjadi 51.068 pada tahun 2017 dan pada tahun 2018 pekerja atau SDM pada bank umum syariah hanya tinggal 49.516 pekerja.

Hal tersebut yang diduga menjadi faktorfaktor yang mempengaruhi terjadinya fluktuasi pada kinerja keuangan sejumlah bank umum syariah. Jika diukur dengan profitabilitas menggunakan indikator return on asset kinerja keuangan bank umum syariah tidak hanya mengalami kenaikan namun juga mengalami penurunan. Setiap tahun ROA menunjukkan fluktuasi yang berbeda-beda. Jika dinilai dari tingakat kesehatan perbankan, bank umum syariah masih tergolong kurang sehat bahkan ada beberapa bank umum syariah yang tergolong tidak sehat. Hal ini dibuktikan dengan nilai ROA yang masih di bawah $0,5 \%$ bahkan sebagian masih di bawah $0 \%$. Bank Indonesia menetapkan batasan atau standar minimal nilai return on asset untuk perbankan adalah sebesar 1,5\% (Barkhowa \& Utomo, 2019).

Berikut adalah fluktuasi kinerja bank syariah yang berdasarkan ROA dari tahun 2016-2018 yang ditampilkan pada tabel 1 .
Tabel 1

ROA Bank Umum Syariah Tahun 2016-2018

\begin{tabular}{|c|l|r|r|r|}
\hline No. & Nama Bank Umum Syariah & $\mathbf{2 0 1 6}$ & $\mathbf{2 0 1 7}$ & $\mathbf{2 0 1 8}$ \\
\hline $\mathbf{1}$ & PT Bank Victoria Syariah & $-0,0114 \%$ & $0,0023 \%$ & $0,0023 \%$ \\
\hline $\mathbf{2}$ & PT Bank Jabar Banten Syariah & $-0,0557 \%$ & $-0,0497 \%$ & $0,0025 \%$ \\
\hline $\mathbf{3}$ & PT Bank Mandiri Syariah & $0,0041 \%$ & $0,0042 \%$ & $0,0062 \%$ \\
\hline $\mathbf{4}$ & PT Bank TPN Syariah & $0,0563 \%$ & $0,0530 \%$ & $0,0503 \%$ \\
\hline $\mathbf{5}$ & PT Bank BCA Syariah & $0,0074 \%$ & $0,0080 \%$ & $0,0083 \%$ \\
\hline $\mathbf{6}$ & PT Bank Panin Dubai Syariah & $0,0022 \%$ & $-0,0121 \%$ & $0,0024 \%$ \\
\hline $\mathbf{7}$ & PT Maybank Syariah Indonesia & $-0,0223 \%$ & $-0,0077 \%$ & $-0,0380 \%$ \\
\hline $\mathbf{8}$ & PT Bank BNI Syariah & $0,0108 \%$ & $0,0088 \%$ & $0,0101 \%$ \\
\hline $\mathbf{9}$ & PT Bank Syariah Bukopin & $0,0047 \%$ & $0,0011 \%$ & $0,0011 \%$ \\
\hline $\mathbf{1 0}$ & PT Bank Mega Syariah & $0,0180 \%$ & $0,0103 \%$ & $0,0063 \%$ \\
\hline $\mathbf{1 1}$ & PT Bank BRI Syariah & $0,0061 \%$ & $0,0032 \%$ & $0,0028 \%$ \\
\hline $\mathbf{1 2}$ & PT Bank Muamalat Indonesia & $0,0014 \%$ & $0,0012 \%$ & $0,0008 \%$ \\
\hline $\mathbf{1 3}$ & PT Bank Aceh Syariah & $0,0054 \%$ & $0,0192 \%$ & $0,0190 \%$ \\
\hline
\end{tabular}

Sumber: data diolah 2019

Dapat kita lihat bahwa ROA sejumlah bank umum syariah pada tahun 2016-2018 masih berada dibawah standar minimum yang telah ditetapkan oleh Bank Indonesia atau masih dibawah 1,5\%. Dengan ROA yang rendah maka hal ini membuktikan bahwa tingkat keuntungan yang telah dicapai oleh sejumlah bank umum syariah sedang mengalami penurunan atau dengan kata lain kinerja keuangan pada bank umum syariah saat ini sedang melemah.

Berdasarkan pembahasan latar belakang di atas, sehingga peneliti mengambil judul "Pengaruh Pengungkapan Identitas Etis Islam, Agency Cost dan Intellectual Capital Terhadap Kinerja Keuangan (Studi Pada Bank Umum Syariah yang Terdaftar di Otoritas Jasa Keuangan Periode 2016-2018)".

\section{TINJAUAN PUSTAKA}

\section{A. Landasan Teoritis}

Ada dua terori yang digunakan dalam penelitian ini yaitu agency theory dan Signaling teory karena kedua teroi tersebut yang paling relevan untuk membahasa pengaruh antara variabel independen dengan varibal dependen dalam penelitian ini yaitu mengenai Bank Umu Syariah yang dapat dijelaskan lebih lanjut sebagai berikut

\section{Agency Theory \\ Agency theory menjelaskan mengenai} hubungan keagenan sebagai sebuah kontrak, dimana satu atau lebih principal menyewa orang lain (agen) untuk melakukan beberapa jasa bagi kepentingan mereka dengan mendelegasikan beberapa wewenang untuk membuat keputusan kepada agen (Jayati, 2016). Menurut (Permanasari, 2010), agency theory menjelaskan bahwa hubungan agency akan muncul ketika principal mempekerjakan orang lain atau yang disebut agen untuk memberikan suatu jasa dan kemudian principal memberikan wewenang kepada agen tersebut untuk membuat keputusan. Agency 
theory digunakan dalam mengatasi masalah yang terjadi dalam hubungan keagenan.

\section{Signalling Theory}

Signalling theory adalah teori yang menekankan kepada pentingnya informasi yang dikeluarkan oleh perusahaan bagi keputusan investasi dari pihak luar perusahaan. Menurut (Ross, 1977) dalam (Fadhillah, 2018), signalling theory menggambarkan bahwa pihak eksekutif perusahaan memiliki informasi lebih banyak mengenai perusahaan, sehingga terdorong untuk memberikan informasi kepada investor mengenai perusahaan guna meningkatkan saham. Informasi yang diberikan dapat berupa informasi keuangan ataupun nonkeuangan (Rustiarini, 2010).

\section{Resources-Based Theory}

Dalam artikelnya dengan judul "A Resources - based view of the firm" (Wernerflt, 1984) dalam (Jayati, 2016), pertama kalinya disampaikan Resources Based Theory. Resources Based Theory adalah teori yang menjelaskan mengeni sumber daya yang ada pada perusahaan yang dapat dijadikan keunggulan untuk bersaing dan mampu mengarahkan perusahaan untuk memiliki kinerja jangka panjang yang baik. Pembahasan dalam teori ini adalah mengenai sumber daya yang dimiliki perusahaan dan bagaimana perusahaan tersebut dapat mengolah, mengelola dan memanfaatkan sumber daya yang dimiliki.

\section{Kinerja Keuangan}

Menurut (Yuniar, 2013) mendefinisikan kinerja keuangan adalah sebagai kemampuan suatu perusahaan dalam menggunakan finansial untuk mendapatkan profit yang direncanakan. Kinerja keuangan bank merupakan gambaran mengenai kondisi keuangan bank pada suatu periode tertentu, meliputi aspek penghimpunan dan penyaluran dana yang biasanya diukur dengan indikator kecukupan modal, likuiditas, dan profitabilitas bank. Menurut (Ningtyas et.al. 2013) dalam (Jayati, 2016), mengasumsikan bahwa kinerja keuangan bank yang sehat dapat menumbuhkan kepercayaan masyarakat begitu pula sebaliknya, penurunan kinerja keuangan bank dapat menurunkan kepercayaan masyarakat.

$$
\text { ROA }=\frac{\text { Laba Bersih }}{\text { Total Aset }} \times 100 \%
$$

\section{Pengungkapan Identitas Etis Islam}

Menurut (Haniffa \& Hudaib, 2007), Islamic ethical identity merupakan nilai-nilai yang mendasari, penyediaan produk dan layanan bebas bunga, pembatasan untuk transaksi yang dapat diterima secara Islam, fokus pada tujuan sosial perkembangan, tunduk pada tinjauan tambahan oleh Dewan Pengawas Syariah. Pengukuran pengungkapan dapat dilakukan melalui Ethical Identity index dalam laporan keuangan tahunan perbankan syariah tersebut.
Terdapat 5 dimensi pengukuran identitas etis dengan total 27 indikator. Rumus dari Ethical Identity Index (EII) yang dapat digunakan untuk mendapatkan hasil dari penelitian mengenai pengungkapan nilai-nilai etika (Muhibbai \& Basri, 2017) adalah sebagai berikut:

$$
E I I j=\frac{\sum_{i=1}^{n j} X i j}{n j} x 100 \%
$$

Ket:

EIIj = Ethical Identity Index (EII)

$n j=$ jumlah indikator diungkapkan oleh perusahaan pada masing masing dimensi

Xij = jumlah indikator ideal yang harus diungkapkan pada masing-masing dimensi

\section{Agency Cost}

Menurut (Muchlas \& Alamsyah, 2017), agency cost yaitu insentif yang diberikan kepada manajer sebagai agen untuk melaksanakan pengawasan agar manajer melakukan fungsinya sejalan dengan tujuan pemegang saham. (Muhibbai \& Basri, 2017), pengukuran agency cost dilakukan melalui rumus:

$$
\mathbf{A C}=\frac{\text { Operating Expense }}{\text { Net Sale }}
$$

\section{Intellectual Capital}

Intellectual capital adalah sumber daya yang dimiliki oleh perusahaan, modal intelektual adalah ilmu pengetahuan atau daya pikir, yang dimliki oleh perusahaan, tidak memiliki bentuk fisik (tidak berwujud), dan dengan adanya modal intelektual tersebut, perusahaan akan mendapatkan tambahan keuntungan atau kemapanan proses usaha serta memberikan perusahaan suatu nilai lebih dibanding dengan kompetitor atau perusahaan lain (Ellanyndra, 2011) dalam (Jayati, 2016).

Ket: $\quad \mathrm{VA}=$ Value Added

VA= Out - In

Out $=$ Total Pendapatan

In = Total Beban (selain beban kryawan)

VACA $=$ VA/CE

Ket: $\quad$ VACA= Capital Employed Value Added $\mathrm{CA}=$ Dana yang Tersedia (Total Ekuitas)

VAHU $=$ VA/HC

Ket: $\quad$ VAHU = Human Capital Value Added

$\mathrm{HC}=$ Beban Karyawan

STVA $=$ SC/VA

Ket: $\quad$ STVA= Structur Capital Value Added $\mathrm{SC}=\mathrm{VA}-\mathrm{HC}$

Rumus yang akan digunakan dalam mengukur intellectual capital adalah: 


$$
\text { iB_VAIC = VACA + VAHU + STVA }
$$

\section{B. Hubungan Antar Variabel}

1. Hubungan Pengungkapan Identitas Etis Islam Terhadap Kinerja Keuangan

Pengungkapan identitas etis Islam adalah sebuah informasi yang disampaikan perusahaan mengenai fungsinya sebagai sebuah entitas yang menjalankan kegiatan operasional berdasarkan prinsip dan ketentuan hukum Islam. Pengungkapan identitas etis Islam yang dilakukan perbankan syariah tersebut merupakan sebuah signal yang diberikan perbankan dengan tujuan untuk memberikan good news kepada public guna mempertahankan dan meningkatkan kepercayaan masyarakat. Semakin tinggi nilai pengungkapan identitas etis Islam, hal ini menunjukkan semakin tinggi juga tingkat kepatuhan perbankan terhadap prinsip-prinsip Islam. Hal ini akan menghasilkan komitmen dan loyalitas masyarakat, dan akhirnya akan berdampak pada kinerja keuangan..

2. Hubungan Agency Cost Terhadap Kinerja
Keuangan
Timbulnya agency cost disebabkan oleh terjadinya pemisahaan antara dua fungsi dalam perusahaan yaitu fungsi pengelolaan dan fungsi kepemilikan. Terjadinya pemisahaan ini menyebabkan timbulnya asimetri informasi. (Jensen \& Meckling, 1976) dalam (Muhibbai \& Basri, 2017), mengatakan bahwa pemisahan fungsi pengelolaan dan fungsi kepemilikan sangat rentan dengan konflik kepentingan (agency conflict). Hal ini timbul karena agen dalam membuat keputusan cenderung hanya mempertimbangkan kepentingan pribadi tanpa memperhatikan kepentingan principal. Agency conflict ini lah yang menimbulkan adanya agency cost sehingga terjadinya aliran kas untuk bonus ataupun insentif yang akan diberikan kepada agen-agen yang melakukan pengawasan untuk mencegah terjadinya penyalahan wewenang yang dapat dilakukan di dalam perusahaan.

Ketika principal berupaya untuk mengendalikan sumber daya organisasi, maka orientasinya adalah untuk meningkatkan kesejahteraan mereka. Kesejahteraan tersebut diwujudkan dengan semakin tingginya return yang dihasilkan oleh organisasi maka semakin besar biaya yang dikeluarkan oleh principal untuk membayar agen dalam memantau dan memastikan manajer bertindak konsisten dan sesuai dengan persetujuan kontrak antara manajer, prinsipal dan kreditur. Pengeluaran ini juga akan mempengaruhi laporan keuangan dan akan berdampak pada kinerja keuangan.
3. Hubungan Intellectual Capital Terhadap Kinerja Keuangan
Menurut (Widarjo, 2011) dalam (Jayati, 2016), mengatakan bahwa melalui pendekatan resources

based-theory dijelaskan bahwa perusahaan akan dapat unggul dalam usaha dan akan mendapatkan kinerja keuangan yang baik dengan cara memiliki, menguasai dan memanfaatkan aset-aset strategis termasuk aset berwujud dan tidak berwujud. Sumber daya manusia merupakan salah satu hal yang penting dalam menjalankan bisnis, apabila perusahaan mampu mengelola sumber daya yang dimiliki secara efektif maka hal itu dapat menciptakan keunggulan kompetitif bagi perusahaan. Dengan pengelolaan potensi yang dimiliki karyawan secara baik, maka hal itu akan dapat meningkatkan produktivitas karyawan. Jika produktivitas karyawan meningkat, maka kinerja perusahaan pun akan meningkat. (Chen et.al. 2005) dalam (Jayati, 2016), juga membuktikan bahwa IC $\left(\mathrm{VAIC}^{\mathrm{TM}}\right)$ dapat menjadi salah satu dari indikator yang dapat memprediksi kinerja perusahaan di masa mendatang.

\section{Kerangka Konseptual}

Atas dasar analisis tersebut, maka pengaruh dari masing-masing variabel terhadap penyaluran kredit dapat digambarkan dalam kerangka konseptual berikut ini:

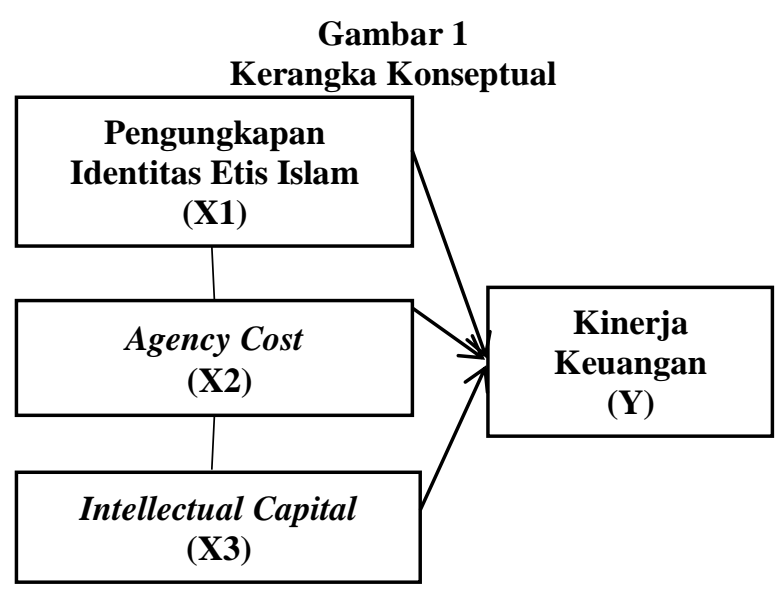

\section{Hipotesis}

Berdasarkan teori dan perumusan masalah yang dikemukakan sebelumnya, hipotesis dalam penelitian ini adalah:

$\mathrm{H}_{1}$ : secara persial pengungkapan identitas etis Islam berpengaruh signifikan terhadap kinerja keuangan bank umum syariah yang terdaftar di otoritas jasa keuangan periode 2016-2018.

$\mathrm{H}_{2}$ : secara persial agency cost berpengaruh signifikan terhadap kinerja keuangan bank umum syariah yang terdaftar di otoritas jasa keuangan periode 2016-2018.

$\mathrm{H}_{3}$ : secara persial intellectual capital berpengaruh signifikan terhadap kinerja keuangan bank umum syariah yang terdaftar di otoritas jasa keuangan periode 2016-2018. 


\section{METODE PENELITIAN}

\section{A. Objek dan Lokasi Penelitian}

Dalam sebuah penelitian yang pertama kali dilakukan adalah menentukan objek penelitian yang akan diteliti, dimana objek tersebut telah mencakup fenomena yang akan dijadikan bahan penelitian untuk kemudian mencari solusi dalam pemecahan masalah tersebut. Menurut (Sugiyono, 2017), mengatakan bahwa objek penelitian ialah variabel penelitian yang berkenaan dengan inti dari problematika penelitian. Yang menjadi objek dalam penelitian ini adalah Pengungkapan Identitas Etis Islam $\left(\mathrm{X}_{1}\right)$, Agency Cost $\left(\mathrm{X}_{2}\right)$, Intellectual Capital $\left(\mathrm{X}_{3}\right)$, dan Kinerja Keuangan (Y). Penelitian dilakukan pada bank umum syariah yang terdaftar di OJK selama periode 2016-2018. Bank BUMN yang terdaftar di OJK yaitu: Bank Muamalat Indonesia, Bank Victorya Syariah, Bank BRI Syariah, Bank Jabar Banten Syariah, Bank BNI Syariah Bank, Mandiri Syariah, Bank Mega Syariah, Bank Panin Dubai Syariah, Bnak Syariah Bukopin, Bank BCA Syariah, Bank Tabungan Pensiun Syariah, Maybank Syariah, Bank Aceh Syariah.

\section{B. Populasi dan Sampel}

Menurut (Sugiyono, 2013) populasi ialah suatu wilayah generalisasi yang terdiri dari objek atau subjek serta mempunyai kualitas dan karakteristik tertentu yang ditetapkan oleh peneliti untuk dipelajari, kemudian ditarik kesimpulannya. Populasi yang digunakan dalam penelitian ini adalah bank umm syariah yang terdaftara di OJK dari tahun 2016 sampai dengan tahun 2018 sebanyak 14 BUS yaitu: Bank Muamalat Indonesia, Bank Victorya Syariah, Bank BRI Syariah, Bank Jabar Banten Syariah, Bank BNI Syariah Bank, Mandiri Syariah, Bank Mega Syariah, Bank Panin Dubai Syariah, Bnak Syariah Bukopin, Bank BCA Syariah, Bank Tabungan Pensiun Syariah, Maybank Syariah, Bank Aceh Syariah, Bank Nusa Tenggara Barat Syariah. Menurut (Sugiyono, 2013), sampel ialah bagian dari jumlah dan karakteristik yang dimiliki oleh populasi tersebut. Pengambilan sampel dilakukan dengan metode purposive sampling. Purposive sampling adalah metode penarikan sampel dengan menetapkan kriteria tertentu (Kuntjojo, 2009:35). Adapun kriteria pemilihan sampel yang digunakan adalah sebagai berikut:

1. BUS yang terdaftar di OJK selama periode 2016-2018

2. BUS yang mempublikasikan laporan tahunan secara lengkap selama periode tahun 20162018 pada website resming masing-masing dan sesuai PSAK 101 tentang penyajian laporan keuangan syariah.

\section{Jenis dan Sumber Data}

Data yang digunakan dalam penelitian ini adalah data sekunder, (Sugiyono, 2017) mengatakan bahwa data sekunder merupakan data yang diperoleh secara tidak langsung baik dari buku, catatan, bukti yang telah ada atau arsip yang dipublikasikan maupun tidak dipublikasikan. Adapun data sekunder dalam penelitian ini bersumber dari laporan tahunan bank umum syariah periode 2016-2018.

\section{Teknik Pengumpulan Data}

Dalam penelitian ini, peneliti melakukan beberapa metode pengumpulan data sesuai dengan masalah yang diteliti. Teknik pengumpulan data yang digunakan dalam penelitian ini adalah metode dokumentasi. (Sugiyono, 2017) mengatakan bahwa metode dokumentasi yaitu data dikumpulkan dari bukti dan dokumen-dokumen yang berkaitan dengan objek penelitian, pada penelitian ini berupa laporan keuangan yang telah dipublikasikan kepada masyarakat.

\section{E. Uji Asumsi Klasik \\ 1. Uji Normalitas}

Uji normalitas dilakukan untuk menguji apakah dalam model regresi, variabel depende dan variabel independennya memiliki distribusi normal atau tidak. Terdapat dua cara untuk mendeteksi data berdistribusi normal atau tidak yaitu dengan analisis grafik dan analisis statistik. (Arfan et.al. 2018:276). Pada penelitian ini, akan dilakukan analisis statistik Kolmogorov-Smirnov (KS) untuk mendeteksi normalitas data dan residual. Penelitian ini menggunakan taraf signifikansi 5\%, dimana jika nilai signifikansi dari nilai KS > 5\%, maka data yang digunakan dalam penelitian berdistribusi secara normal, sebaliknya jika nilai signifikansi dari nilai $\mathrm{KS}<5 \%$, maka data yang digunakan dalam penelitian tidak berdistribusi secara normal (Ghozali, 2012b).

\section{Uji Autokorelasi}

Uji autokorelasi bertujuan untuk mengevaluasi apakah dalam model yang akan diteliti ada korelasi antar kesalahan penggangu (residual) pada tahun sekarang dengan kesalahan pada tahun sebelumnya. Autokorelasi muncul karena observasi yang berurutan sepanjang waktu berkaitan satu sama lain (Ghazali, 2009).

Untuk menguji autokorelasi dapat dilihat dari nilai Durbin Waston (DW), yaitu apabila nilai DW berada dibawah -2 maka terjadinya autokorelasi positif namun jika nilai DW berada diantara -2 sampai 2 maka itu berarti tidak ada terjadinya autokorelasi, akan tetapi jika nilai DW berada diatas nilai 2 berarti terjadinya autokorelasi negative (Arfan et.al. 2018:276).

\section{Uji Heterokedasitas}

Uji heteroskedastisitas bertujuan untuk menguji apakah sebuah model regresi terjadi ketidaksamaan varians residual dari satu pengamatan ke pengamatan yang lain. Jika varians residual dari satu pengamatan ke pengamatan yang lain tetap, maka terjadi heteroskedastisitas (Ghozali, 2016). Adapun cara untuk mendeteksi ada atau tidaknya heteroskedastisitas dengan melihat grafik plot antara nilai prediksi variabel dependen yaitu ZPRED dengan residualnya SRESID. Jika terdapat pola tertentu seperti titik-titik yang ada membentuk suatu pola tertentu yang teratur (bergelombang, melebar, 
kemudian menyempit) maka terjadi heteroskedastisitas. Sebaliknya jika tidak terdapat pola yang jelas serta titik-titik menyebar diatas dan dibawah angka 0 (nol) pada sumbu Y, maka tidak terjadi heteroskedastisitas.

\section{Uji Multikolineritas}

Uji ini bertujuan untuk mengevaluasi apakah pada model regresi yang akan dilakukan terdapat adanya korelasi antar variabel. Ada beberapa cara untuk mendeteksi terjadinya multikolonearitas dalam model regresi (Ghozali, 2005):

1. Nilai $\mathrm{R}^{2}$ yang dihasilkan oleh suatu estimasi model empiris sangat tinggi, tetapi secara individual variabel-variabel bebas banyak yang tidak signifikan mempengaruhi variabel terikatnya.

2. Menganalisa matrik korelasi antar variabel bebas jika terdapat korelasi antar variabel bebas yang cukup tinggi $(>0.9)$ hal ini juga merupakan ada terjadinya multikolonearitas.

3. Dilihat dari nilai varians inflation factor (VIF) pada model regresi. Sebagai acuan dapat disimpulkan:

a. Jika nilai VIF $<10$, maka tidak adanya multikolonearitas antar variabel independen dalam model regresi.

b. Jika nilai VIF > 10, maka dapat disimpulkan bahwa ada multikolonearitas antar variabel independen didalam model regresi.

Pada penelitian ini, dalam mendeteksi gejala multikolonearitas diamati dengan melihat nilai varians infaltion factor (VIF) pada model regresi. Dimana suatu model dapat dikatakan terbebas dari gejala multikolonearitas jika nilai tolerance lebih besar dari 0.10 semua variabel independen dan nilai VIF antar variabel independen lebih kecil dari 10 (Gudono, 2012).

\section{F. Metode Analisis Data}

Metode analisis data yang digunakan dalam penelitian ini adalah analisis regresi linear berganda. Analisis regresi linear berganda merupakan suatu teknik statistik yang diukur melalui koefisien parameter, untuk dapat mengetahui seberapa besar pengaruh variabel independen terhadap variabel dependen. Dalam penelitian ini analisis regresi linier berganda digunakan untuk menunjukkan pengaruh dari variabel pengungkapan identitas etis Islam, agency cost dan intellectual capital terhadap kinerja keuangan. Adapun model regresi dalam penelitian ini adalah sebagai berikut:

$$
\mathbf{Y}=\alpha+\beta_{1} X_{1}+\beta_{2} X_{2}+\beta_{3} X_{3}+e
$$

$\begin{array}{ll}\text { Dimana: } & \\ \mathrm{Y} & : \text { Kinerja Keuangan } \\ \alpha & : \text { Konstanta } \\ \beta_{1}, \beta_{2}, \beta_{3}, \beta_{4}, & : \text { Koefisien Regresi } \\ \mathrm{X}_{1} & \text { : Pengungkapan Identitas Etis Islam } \\ \mathrm{X}_{2} & : \text { Agency Cost } \\ \mathrm{X}_{3} & : \text { Intellectual Capita } \\ \mathrm{e} & \text { : Kesalahan residual (Koefisien Error) }\end{array}$

\section{G. Pengujian Hipotesis}

1. Uji Secara Parsial (Uji t)

Uji statistik $t$ pada dasarnya menunjukkan seberapa jauh pengaruh satu variabel independen secara terpisah (individual) dalam menerangkan variasi variabel dependen. Uji t dilakukan dengan tingkat keyakinan 95\% dan tingkat kesalahan analisa (a) 5\% derajat kebebasan (degree of freedom) yang digunakan adalah $\mathrm{df}=\mathrm{n}-\mathrm{k}$. Taraf nyata inilah yang akan digunakan untuk mengetahui kebenaran hipotesis (Ghozali, 2011).

Menurut (Ghozali, 2011) dasar pengambilan keputusan pada uji t adalah sebagai berikut:

1. Jika $t_{\text {hitung }}<t_{\text {tabel }}$ dengan nilai signifikan $>0,05$, maka maka secara individual tidak ada pengaruh secara signifikan antara variabel independen terhadap variabel dependen.

2. Jika $t_{\text {hitung }}>t_{\text {tabel }}$ dengan nilai signifikan $<0,05$, maka secara individual ada pengaruh secara signifikan antara variabel independen terhadap variabel dependen.

2. Koefisien Determinasi $\left(\mathbf{R}^{2}\right)$

Koefisien determinasi (Adjusted $\mathrm{R}^{2}$ ) dilakukan untuk melihat sejauh mana model ini berpengaruh antara variabel independen dalam menjelaskan variabel dependen. Yang termasuk nilai koefisien determinasi yaitu nilai dari nol sampai dengan satu. Dimana apabila nilai yang dihasilkan mendekati satu yang artinya variabel independen hampir memberikan semua informasi yang diinginkan terhadap dugaan dari variabel dependennya (Ghozali, 2012).

Sedangkan menurut (Gujarati, 2003) koefisien determinasi $\left(\mathrm{R}^{2}\right)$ digunakan untuk mengukur proporsi (bagian) atau persentase total varian dalam $\mathrm{Y}$ yang dijelaskan dalam model regresi. Batasannya adalah 0 $\leq \mathrm{R}^{2} \leq 1$. Suatu $\mathrm{R}^{2}$ sebesar 1 berarti mempunyai pengaruh yang sempurna, sedangkan $r^{2}$ yang bernilai nol dapat disimpulkan tidak terdapat pengaruh antara variabel independen dangan variabel dependen.

\section{HASIL PENELITIAN DAN PEMBAHASAN \\ A. Hasil Analisis Data \\ Statistik Deskriptif}

Statistik deskriptif digunakan agar dapat memberikan gambaran umum tentang objek yang dijadikan sampel pada penelitian ini. Statistif deskriptif menggambarkan hasil data deskriptif statistik yang terdiri dari rata-rata, standar deviasi, maksimum, dan minimum serta jumlah pengamatan. Pada Tabel 2 dibawah ini terlihat bahwa banyaknya observasi yang dilakukan pada penelitian ini sebanyak 39 observasi. 
Tabel 2

Statistik Deskript

Descriptive Statistics

\begin{tabular}{|l|r||r|r|r|r|}
\hline & \multicolumn{1}{|c|}{ N } & \multicolumn{1}{c|}{ Minimum } & Maximum & \multicolumn{1}{l|}{ Mean } & Std. Deviation \\
\hline ROA & 39 & -.056 & .056 & .0036 & .02159 \\
EII & 39 & .593 & .815 & .6007 & .05334 \\
AC & 39 & .581 & 2.547 & 1.2053 & .48657 \\
IB_VAIC & 39 & -2.084 & 3.821 & 1.6152 & 1.15060 \\
\hline
\end{tabular}

sumber: output SPSS 20 (2020)

Berdasarkan tabel 2, dapat kita lihat nilai terendah, tertinggi, dan rata-rata variabel yang diteliti pada bank umum syariah yang terdaftar di OJK tahun 2016-2018 sebanyak 39 pengamatan. Variabel dependen adalah kinerja keuangan yang diukur melalui return on asset (ROA) mempunyai nilai maksimum 0.056 dan nilai minimumnya -0.056 . pada variabel ini diperoleh nilai rata-rata ( mean) sebesar 0.0036 dan standar deviation 0.02159 .

Variabel independen pertama adalah pengungkapan identitas etis islam. Pengungkapan identitas etis islam mempunyai nilai maksimum 0.815 yaitu pada PT Bank BNI Syariah dan nilai minimumnya 0.593 yaitu PT Bank Victoria Syariah, PT Bank Tabungan Pensiun Nasional Syariah dan PT Bank Panin Dubai Syariah. Nilai rata-rata pengungkapan identitas etis islam sebesar 0.6907. Nilai standar deviation sebesar 0.05334 .

Variabel independen yang kedua adalah agency cost. Variabel independen agency cost mempunyai nilai maksimum 2.547 yaitu pada PT Bank Jabar Banten Syariah dan nilai terendahnya yaitu 0.581 PT Bank Tabungan Pensiun Nasional Syariah. Nilai rata-rata agency cost sebesar 1.2053 dan nilai standar deviation sebesar 0.48657 .

Variabel independen yang ketiga adalah intellectual capital. Variabel intellectual capital mempunyai nilai maksimum sebesar 3.821 yaitu pada PT Maybank Syariah dan nilai terendahnya -2.084 yaitu pada PT Bank Jabar Banten Syariah. Nilai rata-rata variabel intellectual capital adalah 1.6152 dengan standar deviation sebesar 1.1506.

\section{Uji Asumsi Klasik}

\section{Uji Normalitas}

Uji normalitas dilakukan untuk menguji apakah dalam model regresi, variabel depende dan variabel independennya memiliki distribusi normal atau tidak. Terdapat dua cara untuk mendeteksi data berdistribusi normal atau tidak yaitu dengan analisis grafik dan analisis statistik. (Arfan et.al. 2018:276). Pada penelitian ini, akan dilakukan analisis statistik
Kolmogorov-Smirnov (KS) untuk mendeteksi normalitas data dan residual. Penelitian ini menggunakan taraf signifikansi 5\%, dimana jika nilai signifikansi dari nilai KS > 5\%, maka data yang digunakan dalam penelitian berdistribusi secara normal, sebaliknya jika nilai signifikansi dari nilai $\mathrm{KS}<5 \%$, maka data yang digunakan dalam penelitian tidak berdistribusi secara normal (Ghozali, 2012b).

\section{Tabel 3}

Uji Normalitas

One-Sample Kolmogorov-Smirnov Test

\begin{tabular}{|ll|c|}
\hline & & Unstandardize d Residual \\
\hline Normal Parameters ${ }^{\mathrm{a}, \mathrm{b}}$ & Mean & 39 \\
& Std. Deviation & $0 \mathrm{E}-7$ \\
Most Extreme Differences & Absolute Positive Negative & .01252633 \\
Kolmogorov-Smirnov Z & .137 \\
Asymp. Sig. (2-tailed) & .130 \\
& -137 \\
& .858 \\
\hline
\end{tabular}

b. Calculated from data.

Berdasarkan uji normalitas pada tabel 3 menunjukkan bahwa nilai nilai Asymp. Sig. (2-tailed) $0.453>0.05$ hal tersebut menunjukkan bahwa data berdistribusi normal (Ghozali, 2009:114). Dengan demikian dapat disimpulkan bahwa pada distribusi residual terdistribusi normal sehingga model regresi memenuhi uji normalitas dan dapat digunakan untuk menguji statistik lainnya.

\section{Uji Autokorelasi}

Menurut Ikhsan et.al (2018) uji autokorelasi digunakan untuk menguji apakah dalam sebuah model regresi linier terdapat korelasi antara kesalahan pengganggu pada periode $\mathrm{t}$ dengan kesalahan pada periode $\mathrm{t}-1$ (tahun sebelumnya).

\section{Tabel 4}

Uji Autokorelasi

Model Summary

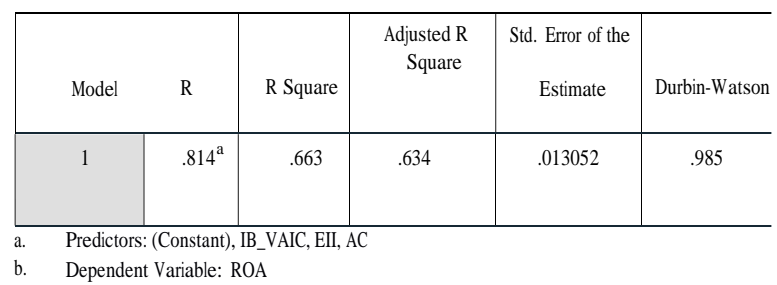

Hasil pengujian dapat dilihat pada tabel 4 menunjukkan bahwa nilai DW sebesar 0.985. hal tersebut membuktikan bahwa nilai DW berada diantara -2 dan 2. Maka dapat disimpulkan bahwa dalam model regresi tidak terjadi autokorelasi.

\section{Uji Heterokedasitas}

Uji heteroskedastisitas bertujuan untuk menguji apakah sebuah model regresi terjadi ketidaksamaan varians residual dari satu pengamatan ke pengamatan yang lain. Jika varians residual dari satu pengamatan ke pengamatan yang lain tetap, maka 
terjadi heteroskedastisitas (Ghozali, 2016). Adapun cara untuk mendeteksi ada atau tidaknya heteroskedastisitas dengan melihat grafik plot Jika terdapat pola tertentu seperti titik-titik yang membentuk suatu pola tertentu yang teratur seperti (bergelombang, melebar, kemudian menyempit) maka terjadi heteroskedastisitas. Sebaliknya jika tidak terdapat pola yang jelas serta titik-titik menyebar diatas dan dibawah angka 0 (nol) pada sumbu Y, maka tidak terjadi heteroskidastisitas.

\section{Gambar 1}

Uji Heterokedastisitas

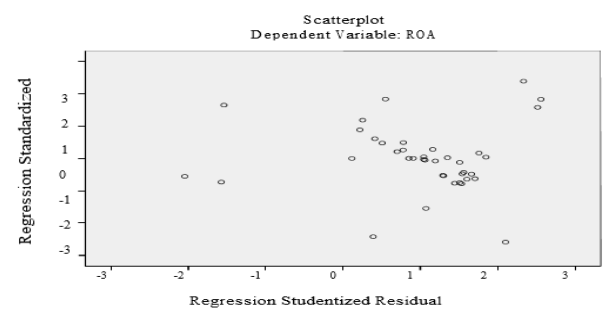

Berdasarkan gambar 1 menunjukkan bahwa tidak ada pola yang jelas, serta titik-titik menyebar diatas dan dibawah angka $O$ pada sumbu $Y$, maka dapat disimpulkan bahwa tidak terjadi heteroskedastisitas.

\section{Uji Multikolinieritas}

Uji ini bertujuan untuk mengevaluasi apakah pada model regresi yang akan dilakukan terdapat adanya korelasi antar variabel. Dalam penelitian ini cara mendeteksi gejala multikolonearitas dengan melihat nilai varians infaltion factor (VIF) pada model regresi. Dimana suatu model dapat dikatakan terbebas dari gejala multikolonearitas jika nilai tolerance lebih besar dari 0.10 semua variabel independen dan nilai VIF antar variabel independen lebih kecil dari 10 (Gudono, 2012).

\section{Tabel 5}

\section{Uji Multikolinieritas} Coefecients ${ }^{a}$

\begin{tabular}{|c|c|c|c|c|c|c|c|}
\hline \multirow[b]{2}{*}{ Model } & \multicolumn{2}{|c|}{$\begin{array}{l}\text { Unstandardized } \\
\text { Coefficients }\end{array}$} & \multirow[t]{2}{*}{$\begin{array}{c}\text { Standardized } \\
\text { Coefficients }\end{array}$} & \multirow{2}{*}{$\mathrm{t}$} & \multirow{2}{*}{ Sig. } & $\begin{array}{r}\text { Collinearity } \\
\text { Statistics }\end{array}$ & \multirow[t]{2}{*}{$\begin{array}{c}\text { Collinearit } \\
y\end{array}$} \\
\hline & B & $\begin{array}{l}\text { Std. } \\
\text { Error }\end{array}$ & & & & Tolerance & \\
\hline 1 (Constant) & .046 & .028 & & 1.639 & .110 & & \\
\hline EII & -.045 & .040 & -.112 & -1.140 & .262 & .992 & 1.008 \\
\hline $\mathrm{AC}$ & -.021 & .005 & -.472 & -4.229 & .000 & .774 & 1.292 \\
\hline IB_VAIC & .009 & .002 & .463 & 4.167 & .000 & .779 & 1.284 \\
\hline
\end{tabular}

Dapat dilihat pada tabel 5, Nilai tolerance semua variabel independen lebih besar dari pada 0.10 dan nilai VIF lebih kecil dari pada 10. Hal tersebut menunjukkan bahwa tidak terjadi multikolinearitas dalam model regresi.

\section{Hasil Analisis Regresi Linier Berganda}

Analisis regresi linier berganda digunakan untuk mengetahui pengaruh antara variabel independen terhadap variabel dependen. Pengaruh antara pengungkapan identitas etis islam, agency cost dan intellectual capital (variabel independen) terhadap kinerja keuangan (variabel dependen) dapat diketahui dengan melihat table 4.6 Berikut ini:

\section{Tabel 6}

Analisis Regresi Linier Berganda Coefecients $^{\mathrm{a}}$

\begin{tabular}{|c|c|c|c|c|c|c|c|}
\hline \multirow[b]{2}{*}{ Model } & \multicolumn{2}{|c|}{$\begin{array}{l}\text { Unstandardized } \\
\text { Coefficients }\end{array}$} & $\begin{array}{c}\text { Standardized } \\
\text { Coefficients }\end{array}$ & \multirow{2}{*}{ t } & \multirow{2}{*}{ Sig. } & $\begin{array}{r}\text { Collinearity } \\
\text { Statistics }\end{array}$ & $\begin{array}{c}\text { Collinearit } \\
y\end{array}$ \\
\hline & B & $\begin{array}{l}\text { Std. } \\
\text { Error }\end{array}$ & Beta & & & Tolerance & VIF \\
\hline (Constant) & .046 & .028 & & 1.639 & .110 & & \\
\hline EII & -.045 & .040 & -.112 & -1.140 & .262 & .992 & 1.008 \\
\hline $\mathrm{AC}$ & -.021 & .005 & -.472 & -4.229 & .000 & .774 & 1.292 \\
\hline IB_VAIC & .009 & .002 & .463 & 4.167 & .000 & .779 & 1.284 \\
\hline
\end{tabular}

Sumber: output SPSS 20 (2020)

Tabel 6 di atas menunjukkan persamaan regresi yang menjelaskan ada atau tidaknya pengaruh antar variabel independen terhadap variabel dependen serta dapat mengetahui besarnya pengaruh variabel independen terhadap variabel dependen. Dari tabel 6 tersebut diperoleh model regresi linier berganda sebagai berikut:

$$
Y=0.046-0.045 X_{1}-0.021 X_{2}+0.009 X_{3}+e
$$

\section{B. Hasil Pengujian Hipotesis dan Pembahasan}

Penelitian ini menggunakan uji $\mathrm{t}$ sebagai penguji hipotesis. Uji $\mathrm{t}$ digunakan untuk melihat pengaruh variabel independen terhadap variabel dependen secara parsial. Adapun kriteria pengambilan keputusannya dengan nilai t-tabel kemudian juga melihat nilai probability. Level kesalahan yang digunakan di dalam penelitian ini adalah sebesar $5 \%$. Adapun pengujian hipotesis di dalam penelitian ini adalah sebagai berikut:

\section{Pengaruh Pengungkapan Identitas Etis Islam Terhadap Kinerja Keuangan}

Berdasarakan hasil pengujian yang dilakukan, maka diketahui variabel identitas etis islam memiliki nilai signifikansi $0.262(26.2 \%)$ lebih besar dari $0.05(5 \%)$ dan nilai $t_{\text {hitung }}<\mathrm{t}_{\text {tabel }}$ yaitu $-1.140<$ 2.030. Hal ini menunjukkan bahwa identitas etis islam tidak berpengaruh signifikan terhadap kinerja keuangan. Dengan demikian hipotesis pertama $\left(\mathrm{H}_{1}\right)$ yang menyatakan bahwa pengungkapan identitas etis Islam berpengaruh signifikan terhadap kinerja keuangan tidak dapat diterima.

Dalam signalling theory menggambarkan bahwa pihak eksekutif perusahaan memiliki informasi 
lebih banyak mengenai perusahaan, sehingga terdorong untuk memberikan informasi kepada investor mengenai perusahaan guna meningkatkan saham. Informasi yang diberikan dapat berupa informasi keuangan ataupun nonkeuangan (Rustiarini, 2010).

Untuk variabel pengungkapan identitas etis Islam merupakan informasi berbentuk nonkeuangan. Informasi tersebut menunjukkan kesesuaian sistem kegiatan operasi perusahaan dengan ketentuanketentuan hukum Islam. Jika dilihat dari sudut pandang nasabah, pengungkapan identitas etis islam bukan hal pertama yang menjadi tolak ukur dalam menentukan pilihan karena ada faktor lain yang lebih menarik perhatian nasabah yaitu besarnya nisbah bagi hasil yang ditawarkan oleh pihak perbankan. Maka oleh karena itu, pengungkapan identitas etis islam tidak menjadi faktor utama dalam meningkatkan kinerja keuangan bank umum syariah (Muhibbai \& Basri, 2017). Barkhowa \& Utomo, (2019) juga menemukan bahwa semakin tinggi atau rendahnya tingkat pengungkapan yang dilakukan oleh pihak bank umum syariah, hal tersebut belum juga dapat mempengaruhi kondisi kinerja keuangan yang dilihat dari return on asset. Hal itu disebabkan karena nilai rata-rata return on asset yang masih dibawah standar minimum yang ditetapkan Bank Indonesia yaitu dibawah $1.5 \%$.

Berdasarkan teori yang telah dijelaskan, maka dapat diambil kesimpulan bahwa yang menjadi salah satu faktor pengungkapan identitas etis Islam tidak berpengaruh terhadap kinerja keuangan disebabkan oleh pihak nasabah atau investor yang lebih tertarik untuk melihat besarnya nisbah bagi hasil yang ditawarkan oleh pihak bank sebelum berinvestasi. Sehingga pengungkapan identitas etis Islam tidak menjadikan faktor utama dalam menentukan pilihan untuk berinvestasi bagi nasabah atau investor, oleh sebab itu hal tersebut tidak dapat mempengaruhi peningkatan terhadap kinerja keuangan.

Hasil penelitian ini sejalan dengan hasil penelitian yang dilakukan oleh (Barkhowa \& Utomo, 2019) yang menemukan bahwa pengungkapan identitas etis islam tidak berpengaruh secara signifikan terhadap kinerja keuangan pada bank umum syariah tahun 2014-2017, dan (Muhibbai \& Basri, 2017) juga menemukan bahwa pengungkapan identitas etis islam tidak berpengaruh signifikan terhadap kinerja keuangan. Namun hasil penelitian ini bertolak belakang dengan hasil penelitian yang dilakukan oleh oleh (Ariyanto, 2014), yang menguji mengenai analisis pengaruh pengungkapan identitas etis Islam terhadap kinerja keuangan yang menyatakan bahwa hasil penelitiannya berpengaruh positif signifikan.

\section{Pengaruh Agency Cost Terhadap Kinerja keuangan}

Berdasarakan hasil pengujian yang dilakukan, maka diketahui variabel agency cost memiliki nilai signifikansi $0.000(0 \%)$ lebih kecil dari $0.05(5 \%)$ dan nialai $\mathrm{t}$ hitung $>\mathrm{t}$ tabel yaitu $-4.229>$ 2.030. hal ini menunjukkan bahwa agency cost berpengaruh negative dan signifikan terhadap kinerja keuangan. Dengan demikian hipotesis kedua $\left(\mathrm{H}_{2}\right)$ yang menyatakan bahwa agency cost berpengaruh signifikan terhadap kinerja keuangan dapat diterima.

Tanda negatif pada koefisien nilai $\mathrm{t}$ hitung menunjukkan bahwa apabila nilai agency cost menurun maka akan meningkatkan kinerja keuangan bank umum syariah tahun 2016-2018, begitu juga sebaliknya apabila terjadi peningkatan terhadap nilai agency cost maka kinerja keuangan (ROA) akan mengalami penurunan. Dalam teori agency ketika ternyadinya agency conflict maka timbullah agency cost atau biaya yang dikeluarkan oleh principal untuk memberikan insentif yang layak kepada agen yang telah melakukan pengawasan agar tidak terjadinya kecurangan dan penyalah gunakan wewenang (Lin, 2006) dalam (Muhibbai \& Basri, 2017). Secara teoritis, principal akan mengeluarkan biaya yang besar demi mendapatkan return yang tinggi. sehingga terjadinya aliran kas untuk bonus ataupun insentif yang akan diberikan kepada agen-agen. Pengeluaran inilah yang akan mempengaruhi laporan keuangan dan akan berdampak pada kinerja keuangan, yang berarti bila agency cost dibiarkan membengkak maka hal tersebut dapat mengurangi pencapain keuntungan kompetitif perusahaan yang berdampak negatif terhadap kinerja keuangan.

Berdasarkan teori yang telah dijelaskan, maka dapat disimpulkan bahwa agency cost yang berpengaruh negatif terhadap kinerja keuangan itu menunjukkan bahwa ada pengaruh negatif yang akan terjadi terhadap kinerja keuangan apabila agency cost meningkat. Pengaruh negatif tersebut terjadi apabila agency cost dibiarkan membengkak, maka hal tersebut dapat mengurangi keuntungan kompetitif bagi perusahaan yang dapat menurunkan kinerja keuangan perusahaan.

Hasil penelitian ini sejalan dengan penelitian yanga dilakukan oleh Lin (2006) dan Wright et.al (2009) serta Fu'adah (2015) yang menemukan bahwa agency cost berpengaruh negative dan signifikan terhadap kinerja keuangan. Namun, Hasil penelitian ini berbeda dengan hasil penelitian yang dilakukan oleh (Muhibbai \& Basri, 2017) yang menunjukkan bahwa agency cost berpengaruh positif signifikan terhadap kinerja keuanga bank umum syariah periode 2010-2014.

\section{Pengaruh Intellectual Capital Terhadap Kinerja Keuangan}

Berdasarakan hasil pengujian yang dilakukan, maka diketahui variabel intellectual capital memliki signifikansi $0.000(0 \%)$ lebih kecil dari 0.05 $(5 \%)$ dang nilai $t_{\text {hitung }}>\mathrm{t}_{\text {tabel }}$ yaitu $4.166>2.030$. hal ini menunjukkan bahwa intellectual capital 
berpengaruh positif dan signifikan terhadap kinerja keuangan. Dengan demikian hipotesis ketiga $\left(\mathrm{H}_{3}\right)$ yang menyatakan bahwa intellectual capital berpengaruh signifikan terhadap kinerja keuangan dapat diterima.

Tanda positif pada koefisien nilai $\mathrm{t}$ hitung menunjukkan bahwa apabila nilai dari variabel intellectual capital meningkat maka akan meningkatkan kinerja keuangan bank umum syariah tahun 2016-2018, begitu juga sebaliknya apabila terjadi penurunan terhadap nilai intellectual capital maka kinerja keuangan (ROA) juga akan mengalami penurunan.

Hasil penelitian ini sejalan dengan hasil penelitian yang dilakukan oleh (Khasanah, 2016) yang menemukan bahwa terdapat pengaruh positif signifikan intellectual capital terhadap kinerja keuangan yang dihitung menggunakan rasio return on asset (ROA). Sesuai dengan resources based theory yang menjelaskan mengeni sumber daya yang ada pada perusahaan yang dapat dijadikan keunggulan untuk bersaing dan mampu mengarahkan perusahaan untuk memiliki kinerja jangka panjang yang baik. Maka hasil penelitian ini memperlihatkan bahwa perusahaan perbankan telah memanfaatkan kemampuan daya pikir karyawannya dalam menciptakan nilai bagi perusahaan. Atas dasar nilai tambah tersebut para penyandang dana akan memberikan nilai tambah juga kepada perusahaan dengan cara meningkatkan nilai investasi, hal ini akan berpengaruh dalam meningkatkan kinerja keuangan perusahaan. Secara teoritis, dalam dunia perbankan intellectual capital sangatlah penting, karena mereka mengandalkan kepercayaan dalam mengelola dana pemilik atau pun dana masyarakat. Perbankan membutuhkan tenaga-tenaga professional dan terampil serta memiliki integritas moral yang baik dan terpercaya dalam menjalankan segela aktivitas di perusahaan. Masa depan dan prospek perusahaan akan bergantung pada kemampuan manajemen dalam mendayagunakan nilai yang tidak tampak dari aset tak berwujud sehingga membawa pengaruh baik terhadap perusahaan. Namun penelitian ini tidak sejalan dengan hasil penelitian dari (Nurhudha \& Suwarti, 2015) yang menyatakan bahwa modal intelektual tidak memengaruhi kinerja keuangan.

Berdasarkan uraian di atas maka dapat disimpulkan bahwa, intellectual capital yang berpengaruh positif signifikan terhadap kinerja keuangan menunjukkan bahwa bank umum syariah telah mengelola dan memanfaatkan sumber daya karyawan dengan baik. Sehingga, kemampuan yang dimiliki karyawan dalam menjalankan semua kegiatan operasional dapat menciptakan nilai tambah dan menjadikannya sebagai keunggulan kompetitif bagi perusahaan, hal tersebut yang meningkatkan kinerja keuangan bagi perusahaan.

\section{Uji Koefisien Determinasi $\left(\mathbf{R}^{\mathbf{2}}\right)$}

Pengujian regresi linier berganda dianalisis pula dengan koefesien determinasi $\left(\mathrm{R}^{2}\right)$. Koefisien determinasi $\left(\mathrm{R}^{2}\right)$ dilakukan untuk melihat sejauh mana model ini berpengaruh antara variabel independen dalam menjelaskan variabel dependen. Yang termasuk nilai koefisien determinasi yaitu nilai dari nol sampai dengan satu. Dimana apabila nilai yang dihasilkan mendekati satu yang artinya variabel independen hampir memberikan semua informasi yang diinginkan terhadap dugaan dari variabel dependennya (Ghozali, 2012). Hasil pengujian ditunjukkan pada tabel 7 .

Tabel 7

Uji Koefisien Determinasi $\left(\mathrm{R}^{2}\right)$ Model Summary $\mathrm{b}$

\begin{tabular}{|c|c|c|c|c|c|}
\hline Model & $\mathrm{R}$ & $\mathrm{R}$ Square & $\begin{array}{c}\text { Adjusted R } \\
\text { Square }\end{array}$ & $\begin{array}{c}\text { Std. Error of the } \\
\text { Estimate }\end{array}$ & Durbin- Watson \\
\hline 1 & $.814^{\mathrm{a}}$ & .663 & .634 & .01305 & .985 \\
\hline
\end{tabular}

b. Dependent Variable: ROA

Sumber: hasil output SPSS 20

Berdasarkan output model summary pada tabel 7, terlihat bahwa ketiga variabel independen tersebut menunjukkan hasil Adjusted $R$ Square sebesar 0.634 atau $63.4 \%$. Hasil tersebut menunjukkan bahwa $63.4 \%$ dari variabel pengungkapan identitas etis islam, agency cost dan intellectual capital, menjelaskan kinerja keuangan. Sedangkan sisanya sebesar $36.6 \%$ dijelaskan oleh variabel lain yang tidak termasuk ke dalam penelitian ini.

\section{PENUTUP}

\section{Kesimpulan}

Berdasarkan hasil penelitian dan pembahasan yang sudah diuraikan diatas, maka peneliti menarik kesimpulan sebagai berikut:

1. Pengungkapan identitas etis islam memiliki nilai signifikan sebsar $0.262>0.05$ sehigga pengungkapan identitas etis islam tidak berpengaruh signifikan terhadap kinerja keuangan (ROA).

2. Agency cost memiliki nilai signifikan $0.000<0.05$ sehingga agency cost berpengaruh signifikan terhadap kinerja keuangan (ROA).

3. Intellectual capital memiliki nilai signifikan 0.000 $<0.05$ sehingga intellectual capital berpengaruh signifikan terhadap kinerja keuangan (ROA).

\section{Keterbatasan Penelitian}

Didalam penelitian ini peneliti menyadari bahwa masih banyak terdapat keterbatasanketerbatasan, antara lain:

1. Pemilihan variabel independen yang diduga berpengaruh terhadap kinerja keuangan hanya melihat tiga faktor saja, yaitu pengungkapan identitas etis islam, agency cost dan intellectual capital. Hal ini memungkinkan terabaikannya 
faktor-faktor lain yang mempengaruhi kinerja keuangan.

2. Periode pengamatan yang tidak panjang, yaitu hanya tiga periode sehingga menyebabkan pengamatan yang terbatas. Penelitian ini juga hanya menggunakan indikator ROA dalam mengukur kinerja keuangan perusahaan, sehingga tidak dapat mengetahui kinerja perusahaan secara keseluruhan

Saran

Berdasarkan pembahasan dan kesimpulan yang diperoleh dari hasil penelitian ini, maka penulis dapat memberikan saran sebagai berikut:

1. Diharapkan bagi penelitian selanjutnya untuk menambah beberapa variabel independen lainnya yang diduga mempengaruhi kinerja keuangan perusahaan seperti struktur modal dan ukuran perusahaan sehingga dapat kita ketahui variabelvariabel apa saja yang dapat memepengaruhi kinerja suatu perusahaan. Selanjutnya, diharapkan juga untuk menambah periode pengamatan agar mendapatkan hasil yang lebih signifikan, serta melihat juga kinerja keuangan dari sisi rasio rentabilitas yang lain salah satunya yaitu dari segi ROE, sehingga dapat diketahui bagaimana kinerja keuangan perusahaan perbankan dari sisi rasio rentabiltas secara keseluruhan.

2. Bagi pihak perusahaan yaitu bank umum syariah, peneliti menyarankan unuk dapat lebih memperhatikan serta dapat memanfaatkan sumberdaya intellectual yang dimiliki dengan efektif, sehingga dapat menciptakan keunggulan kompetitif bagi perusahaan. Dengan pengelolaan potensi yang dimiliki karyawan secara baik, maka hal itu akan dapat meningkatkan produktivitas karyawan. Jika produktivitas karyawan meningkat, maka kinerja perusahaan pun akan meningkat.

\section{KEPUSTAKAAN}

Arikunto, S. (2013). Prosedur Penelitian: Suatu Pendekatan Praktik. Rineka Cipta.

Arfan, I., Albra, W., Aziza, N., Khadafi, M., Hayat, A., Oktaviani, A., \& Lesmana, S. (2018). Metodelogi Penelitian Bisnis untuk Skipsi, Thesis dan Disertasi. Madenatera.

Barkhowa, M. K., \& Utomo, H. (2019). Pengaruh Identitas Etis Islam Dan Market Share Terhadap Kinerja Keuangan Perbankan Syariah Yang Terdaftar Di Otoritas Jasa Keuangan Indonesia Tahun 2014-2017. Magisma: Jurnal Ilmiah Ekonomi Dan Bisnis, vol.7(1), $12-18$. https://doi.org/10.35829/magisma.v7i1.36

Fadhillah, M. D. (2018). Hubungan Tingkat
Kesehatan Bank Terhadap Pengungkpana Identitas Etika Bank Umum Syariah di Indonesia. In fakultas ekonomi dan bisnis universitas lampung bandar lampung. https://doi.org/10.1051/matecconf/20171210700 5

Ghozali, I. (2005). Aplikasi Analisis Multivariate. In Badan Penerbit Universitas Diponegoro: Semarang.

Ghozali, I. (2012a). Aplikasi Analisis Multivariate. In Universitas Diponegoro: Semarang.

Ghozali, I. (2012b). Aplikasi Analisis Multivariate Dengan Program SPSS. In Universitas Diponegoro: Semarang.

Gudono, M. (2011). Anlisis Data Multivariat Edisi Pertama. In BPFE: Yogyakarta.

Gudono, M. (2012). Analisis Data Multivariat Edisi Kedua. In BPFE: Yogyakarta.

Haniffa, R., \& Hudaib, M. (2007). Exploring the ethical identity of Islamic Banks via communication in annual reports. Journal of Business Ethics, 76(1), 97-116. https://doi.org/10.1007/s10551-006-9272-5

Jayati, S. E. (2016). Pengaruh Intellectual Capital Terhadap Kinerja Keuangan Perusahaan Perdagangan Jasa Yang Terdaftar Di Bursa Efek Indonesia. In Universitas Negeri Yogyakarta.

https://doi.org/10.31326/jks.v2i02.162

Muchlas, Z., \& Alamsyah, A. R. (2017). Pengaruh Agency Cost Terhadap Kinerja Keuangan. Jibeka, 11(1), 92-98.

Muhibbai, A., \& Basri, H. (2017). Pengaruh Pengungkapan Identitas Etis Islam, Agency Cost Dan Modal Intelektual Terhadap Kinerja Keuangan. Jurnal Ilmiah Mahasiswa Ekonomi Akuntansi, 2(1), 30-37.

Nurhudha, A. S., \& Suwarti, T. (2015). Analisis Pengaruh Corporate Social Responsisbility, Intellectual Capital, dan Kinerja Lingkungan Terhadap Kinerja Keuangan Perusahaan Manufaktur yang Terdaftar di Bursa Efek Indonesia. Prosiding Seminar Nasional Multi Disiplin Ilmu \& Call For Papers UNISBANK, 53(9), 1689-1699. https://doi.org/10.1017/CBO9781107415324.00 4

Permanasari, W. (2010). Pengaruh Kepemilikan Manajemen, Kepemilikan Institusional dan Corporate Social Responsibility Terhadap Nilai Perusahaan. Universitas Diponegoro. 
Rustiarini, N. W. (2010). Penagruh Corporate Governace Pada Hubungan Corporate Social Responsibility dan Nilai Perusahaan. Jurnal Dan Prosiding Simposium Nasional Akuntansi XIII.

Sugiyono. (2009). Metode Penelitian Bisnis (Pendekatan Kuantitatif, Kualitatif, Dan R\&D). In Alfabeta: Bandung.

Sugiyono. (2012). Metode Penelitian Bisnis. Alfebata.

Sukardi, B., \& Wijaya, T. (2013). Corporate Ethical Identity Perbankan Syariah di Indonesia. Tsaqafah, 9(2), 337. https://doi.org/10.21111/tsaqafah.v9i2.56

Yuniar, S. (2013). Analisis Perbandingan Kinerja Keuangan Pada Perbankan Konvensional dan Syariah dengan Menggunakan Rasio KeuanganBank (Studi Kasus: Bank Syariah Mandiri). Universitas Muhamadiyah Surakarta. 